University of Nebraska - Lincoln

DigitalCommons@University of Nebraska - Lincoln

Faculty Publications, Department of Child, Youth, and Family Studies

Child, Youth, and Family Studies, Department of

September 1999

\title{
LOW-INCOME FATHERS' AND MOTHERS' PERCEPTIONS OF THE FATHER ROLE: A QUALITATIVE STUDY IN FOUR EARLY HEAD START COMMUNITIES
}

\author{
Jean Ann Summers \\ Juniper Gardens Children's Project, University of Kansas \\ Helen Raikes \\ University of Nebraska-Lincoln, hraikes2@unl.edu \\ James Butler \\ University of Pittsburgh Graduate School of Public Health \\ Paul Spicer \\ University of Colorado Health Sciences Center \\ Barbara Pan \\ Harvard Graduate School of Education \\ See next page for additional authors \\ Follow this and additional works at: https://digitalcommons.unl.edu/famconfacpub \\ Part of the Family, Life Course, and Society Commons
}

Summers, Jean Ann; Raikes, Helen; Butler, James; Spicer, Paul; Pan, Barbara; Shaw, Sarah; Langager, Mark; McAllister, Carol; and Johnson, Monique K., "LOW-INCOME FATHERS' AND MOTHERS' PERCEPTIONS OF THE FATHER ROLE: A QUALITATIVE STUDY IN FOUR EARLY HEAD START COMMUNITIES" (1999). Faculty Publications, Department of Child, Youth, and Family Studies. 40. https://digitalcommons.unl.edu/famconfacpub/40

This Article is brought to you for free and open access by the Child, Youth, and Family Studies, Department of at DigitalCommons@University of Nebraska - Lincoln. It has been accepted for inclusion in Faculty Publications, Department of Child, Youth, and Family Studies by an authorized administrator of DigitalCommons@University of Nebraska - Lincoln. 


\section{Authors}

Jean Ann Summers, Helen Raikes, James Butler, Paul Spicer, Barbara Pan, Sarah Shaw, Mark Langager, Carol McAllister, and Monique K. Johnson 
Published in INFANT MENTAL HEALTH JOURNAL, Vol. 20(3), 291-304 (1999).

Copyright (C) 1999 Michigan Association for Infant Mental Health. Published by John Wiley Inc. Used by permission.

\title{
LOW-INCOME FATHERS' AND MOTHERS' PERCEPTIONS OF THE FATHER ROLE: A QUALITATIVE STUDY IN FOUR EARLY HEAD START COMMUNITIES
}

\author{
JEAN ANN SUMMERS \\ Juniper Gardens Children's Project, University of Kansas \\ HELEN RAIKES \\ Administration on Children, Youth and Families \\ JAMES BUTLER \\ University of Pittsburgh Graduate School of Public Health \\ PAUL SPICER \\ University of Colorado Health Sciences Center \\ BARBARA PAN \\ SARAH SHAW \\ MARK LANGAGER \\ Harvard Graduate School of Education \\ CAROL MCALLISTER \\ MONIQUE K. JOHNSON \\ University of Pittsburgh Graduate School of Public Health
}

\begin{abstract}
A qualitative inquiry in four Early Head Start Research sites explored the question of how lowincome mothers and fathers view the role of fathers in their families. Role perceptions were gathered from a total of 56 parents of infants and toddlers across the four sites, using multiple data collection methods that included focus groups, open-ended interviews, and one case study. The data were analyzed to identify common themes across sites. The participants identified roles that included: providing financial support, "being there," care giving, outings and play, teaching and discipline, providing love, and protection. Implications of these qualitative findings are discussed with respect to their relationship to current theoretical frameworks about father roles. Further, these findings shed light on the question of whether low-income families view parenting roles as being relatively discrete (i.e., separate or "traditional" functions of mothers and fathers), or whether they view their roles in a more blended, co-parenting perspective.
\end{abstract}

RESUMEN: Una investigación cualitativa en cuatro lugares de investigación de "Early Head Start," exploró la pregunta de cómo las madres y los padres de bajos recursos económicos ven el papel que ellos tienen dentro de sus familias. Se reunio' información sobre la percepción de su función dentro de la familia, de

Correspondence: Jean Ann Summers, Ph.D., Juniper Gardens Children's Project, 650 Minnesota Ave., Second Floor, Kansas City, KS 66101; Phone: (913)321-3143; Fax: (913) 371-8522. 
parte de un total de 56 padres de infantes en los cuatro lugares, usando para ello múltiples métodos para recoger información, de los cuales se pueden mencionar grupos de enfoque, entrevistas de final abierto, y el estudio de un caso. La información se analizó para identificar temas comunes en todos los lugares. Entre las funciones que los participantes identificaron se incluyen: proveer apoyo económico, estar "ahí" cuando se le necesite, prestar atención y cuidado, paseos y juego, enseñanzas y disciplina, proveer amor, protección. Se discuten las implicaciones de estos resultados cualitativos con respecto a las relaciones que puedan tener con los marcos teóricos actuales acerca del papel de los padres. Es más, estos resultados dan luz a la pregunta de si las familias de bajos recursos económicos perciben los papeles de padres y madres como algo relativamente distinto (por ejemplo, funciones separadas o tradicionales para las madres y para los padres), o si ellos ven sus funciones de una manera más mezclada desde una perspectiva de crianza compartida en colaboración

RÉSUMÉ: Une enquête quantitative dans quatre sites de Recherche sur les Programmes d'Aide Précoca á l'Enfance Défavorisée (aux Etats-Unis) a exploré la manière dont les mères et pères de milieux pauvres et défavorisés conçoivent le rôle des pères dans leurs familles. Les perceptions de rôle ont été recueillies à partir d'un total de 56 parents de nourrissons ou enfants en bas âge dans les quatre sites, en utilisant des méthodes de recueil de données diverses, comprenant des groupes de mise au point, des entretiens ouverts, et une étude de cas. Les données ont été analysées pour identifier les thèmes communs à tous les sites. Les participants ont identifié des rôles qui incluaient: offrir un soutien financier, "être lá", s'occuper de l'enfant, sorties et jeu, l'enseignement et la discipline, donner de l'amour, et la protection. Les implications de ces résultats qualitatifs ont discutées à l'égard de leurs relations aux structures théoriques actuelles sur les rôles du père. De plus, ces résultats aident à mieux comprendre la question selon laquelle les familles de milieux pauvres et défavorisés conc, oivent les rôles de parentage comme étant relativement discrets (c'est-à-dire des fonctions séparées ou "traditionnelles" des mères et des pères) ou s'ils voient leur rôle dans une perspective plus fondue mettant l'accent sur le co-parentage.

ZUSAMMENFASUNG: Eine qualitative Befragung bei den "Vier Fru"her Kopf Beginne" Untersuchungsorten ging der Frage nach, wie Angehörige von Schichten mit niedrigem Einkommen die Rolle des Vaters in ihren Familien sehen. Die Rollenwahrnehmung wurde aus einer Untersuchungsgruppe von 56 Eltern von Kleinkindern und Krabblern in den vier Ortschaften gesammelt. Wir verwendeten zur Erfassung der Daten spezialisierte Gruppen, Interviews mit offenem Ende und eine Fallgeschichte. Die Daten wurden nach ihrer Gültigkeit über die einzelnen Ortschaften hinaus, analysiert. Die Teilnehmer identifizierten Rollen wie: Stellt das Geld zur Verfu" gung, "ist da", betreut, unternimmt etwas und spielt, lehrt und diszipliniert, liebt und schützt. Die Bedeutung unserer qualitativen Ergebnisse werden vor dem Hintergrund der derzeitigen theoretischen Annahmen über die Rolle des Vaters diskutiert. Darüber hinaus werfen unsere Ergebnisse Licht auf die Frage, ob Familien aus Schichten mit niedrigem Einkommen ihre Rollen als Eltern relativ diskret (das heißt deutlich unterschieden, oder "traditionelle" Rollen von Müttern und Vätern), oder ob sie ihre Rollen in einer mehr gemischten, partnerschaftlichen Sicht sehen.

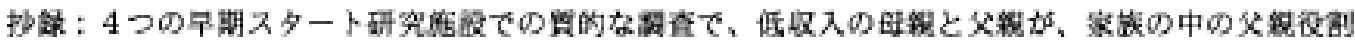

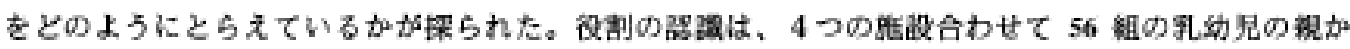

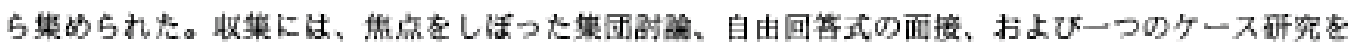

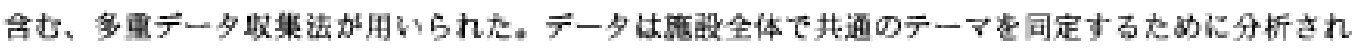

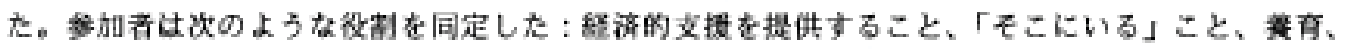

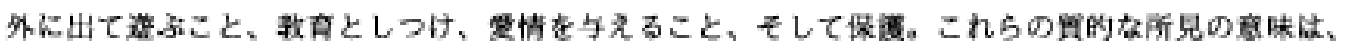

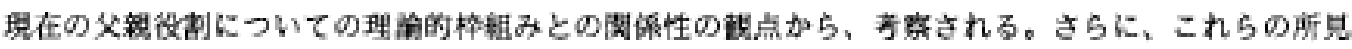

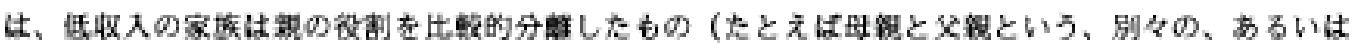

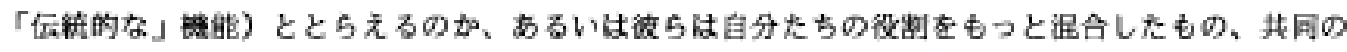

新 cm-parenting という見方でとらえるのか、という疑閔に、光を投げかる。 
The role of the father increasingly is the object of public attention. From the President's Fatherhood Initiative to state initiatives to increase father involvement and paternal support, public attention has been on fathers. Opinions expressed in the popular media, through public policy, and through research, all suggest that enhancing fathers' appropriate involvement with their children will have positive outcomes for children's well-being. In low-income families it seems particularly important to encourage positive father involvement, since some studies suggest the active presence of a father may be an insulating factor against the negative effects of poverty (e.g., McLanahan, Astone, \& Marks, 1991). However, it is not always clear what a number of features related to "encouraging positive father involvement" mean, given a lack of clarity about role expectations for fathers today (Doherty, Kouneski, \& Erickson, 1998). Doherty et al. (1998) suggest that expectations for fathers and mothers currently lack clarity: for women, there is debate concerning mother roles outside the home and for men there is debate about fathers' roles within the family. A first step toward developing public policy and service interventions designed to enhance father involvement, therefore, is a more thorough understanding of the perceptions mothers and fathers have about fathers' roles, and how those perceptions are evolving within the context of the ongoing public dialogue about the changing roles of men and women in our society. Further, it is important to consider both men's and women's perceptions about fathers' roles, because maternal perception of the father role affects paternal perception of the role and a father's actual involvement with children (McBride \& Rane, 1997). Peplau (1983) offers a definition of role as "a consistent pattern of individual activity that is directly or indirectly interdependent with the partner" (p. 222), and stresses the importance of both partners in determining the others' roles. McBride and Rane (1997) emphasize that great variability in paternal role perceptions points to the importance of the mother for assisting the father in establishing role parameters.

More is known about paternal role perceptions of middle-income fathers than of lowincome fathers. Less is known about how paternal and maternal role perceptions interplay when it comes to low-income fathers and mothers; less still is known about the interplay between lowincome parents of infants and toddlers. Understanding how mothers and fathers of low-income infants and toddlers perceive the paternal role provides a stepping stone to understanding father involvement with these very young children. In recent years, investigations of father involvement have used a theoretical framework suggested by Lamb, Pleck, Charnov and Levine (1987), which proposes a content-free, three-part model of father involvement: interaction or direct engagement between father and child; accessibility or avai ability to the child, and taking responsibility for the child (see, e.g., McBride \& Rane, 1997; Marsiglio, Day et al., 1997). This framework appears to be emerging as a generally accepted view of the critical dimensions of positive fathering (McBride \& Rane, 1998).

Expanding upon the work of Lamb and colleagues (1987) and that of others, McBride and Rane (1997) explored middle-income fathers' perceptions of paternal roles. Positive paternal role perceptions have been found to be inversely related to perceptions of work (Lamb, Frodi, Hwang, \& Frodi 1982); and positively related to playful and affiliative care giving behaviors (Levy-Shiff \& Israelashvili, 1988). McBride and Rane (1997) argue for the need to understand fathers' perceptions of commitment, investment, and salience in father roles underscoring the importance of the father's identity in the study of paternal role perception. In other words, for these authors the first question to consider is whether fathers are perceived as important in the life of the child altogether; while the second question is, which roles do fathers perceive as important and appropriate for them to fulfill.

Pleck and Pleck (1997) argue that the role expectations for fathers have shifted from genial dad and breadwinner to equal co-parent. In other words, the more traditional dichotomy of roles features mothers as expressive nurturers and homemakers, and fathers as breadwinners 
and instrumental guides to the outside world. This dichotomy has fallen away in the face of increasing participation by women in the labor force, and shifts in attitude about definitions of "masculinity" and "femininity." Both feminists and fathers' rights groups are demanding a more egalitarian approach to defining parental roles (Silverstein, 1996). It appears that the emerging perception of fatherhood in the late twentieth century is one of father as equal coparent (Pleck \& Pleck, 1997). Indeed, studies of involvement suggest that there is evidence of increasing engagement, accessibility, and responsibility of fathers over the last 20 years, in keeping with the shift toward this co-parenting conception (Pleck, 1997). However, it is also true that fathering and father roles are even more bound to cultural context than mother's roles (Doherty et al., 1998). Thus, if the "traditional" perception of mother/father roles is that each parent fulfills separate and discrete functions, while the "co-parenting" perception is that mothers and fathers share equally in all functions, then one could expect wide variances among cultural subgroups in their perceptions about what is appropriate.

For example, a study of the relationships of fathering and acculturation among immigrant Indian families found that fathers who were more strongly acculturated were more involved in almost all dimensions of fathering (Jain \& Belsky, 1997). Research on the role perceptions of African-American fathers have emphasized the saliency of the more traditional economic provider role. In a study of African-American letter carriers, Cazenave (1979) showed that the economic provider role was the most salient aspect of the paternal role cluster, and a more recent study by Bryan and Ajo (1992) reported that role perceptions of African-American fathers were shaped to a large degree by economic concerns. Price-Bonham and Skeen (1979) report that African-American and Caucasian fathers are more similar than dissimilar in participation and attitudes toward the father role in the 1970s. Finally, in a study of AfricanAmerican teenage fathers (Allen \& Doherty, 1996), the participants were unanimous in their opinion that fathers were very important to families, and pointed to the roles of providers of economic and emotional support, "holding the family together," and providing leadership to the family.

When it comes to low-income families, studies suggest that fathers' perception of the primacy of more traditional, provider roles may be prominent. For example, some research indicates that fathers who perceive themselves as less than adequate providers (e.g., through job loss or poverty) tend to have reduced and/or negative interactions with their children (Harold-Goldsmith, Radin, \& Eccles, 1988; Jones, 1991; LaRossa \& Reitzes, 1993). Mincy (1997) presents a paradigm for paternalism that emphasizes child support and family building roles as essential to assuring father involvement for men in fragile families, defined as those with out of wedlock births in which the parents do not immediately marry or establish paternity.

Certainly, more empirical work needs to be done to fully examine the process of whether a transition is in fact occurring in role perceptions, and if so, the actual father behaviors this may represent in middle-income families. With respect to low-income families, an intriguing question is whether a similar shift toward co-parenting role expectations is also occurring. If so, then the question becomes one of whether a particular combination of expectations for involvement can serve as a protective factor to override the barriers and negative risks to positive fathering that appear to be associated with poverty, as Lamb (1987) suggests.

This study is an exploratory first step toward addressing these questions. Its purpose is to explore the meaning of fatherhood to low-income mothers and fathers of infants and toddlers. Specifically, the question is: What do low-income mothers and fathers perceive as appropriate roles for fathers of young children? 


\section{METHOD}

This study was part of an initiative of the Early Head Start (EHS) Research Consortium, to explore issues related to fathers of infants and toddlers in low-income families, and their involvement in the EHS programs. The EHS Research Consortium consists of 17 Early Head Start programs and their local research partners, as well as a national contractor coordinating a national data collection on families who had been randomly assigned to program and comparison groups in the 17 sites. This study was a part of a supplementary study of that larger effort; its purposes were to develop preliminary information about fathers and father involvement, and to identify directions for more extensive and longer term quantitative and qualitative investigations, to parallel the work being done with mothers in the original Research Consortium design. The qualitative component of that study was a type of "grounded theory" research, with the purpose of inductively gathering information and organizing it into a set of hypotheses or frameworks (Glaser \& Strauss, 1967; Strauss\& Corbin, 1990). Among the research questions posed for this pilot study, the broad question relevant to this report was: "How do participants define the meaning of fatherhood, and what are the perceived benefits and responsibilities of the role of fathers?"

The pilot study team consisted of EHS Research Partner programs located in Denver, Colorado; Kansas City, Kansas; Pittsburgh, Pennsylvania; and Brattleboro, Vermont. These four sites were chosen as a type of purposive sampling strategy (Rubin \& Rubin, 1995), designed to select representatives of salient characteristics of the overall population. The four sites represented, respectively: Hispanic families, two urban poor, mixed African-American and Caucasian communities, and rural Caucasian families. All were within the low-income guidelines for eligibility for Early Head Start. Because it was a pilot study, the team decided to eliminate some potential variance by focusing primarily on fathers who are currently involved with their children. Also, it was thought that involved fathers would have experiences that might make them more articulate on the topic of fatherhood, and therefore potentially good "key informants" with whom to initially explore the issues (Goetz \& Lecompte, 1984). Thus, this study is intended to serve as a basis of comparison for future studies of fathers who have become disengaged from their families and children.

The data collection methods involved methodological triangulation, or the use of multiple methods to study a single problem (Janesick, 1994). In Denver and Brattleboro, the methodology used was the use of separate focus groups of fathers and mothers; in Kansas City, the methodology involved unstructured interviews with mothers, fathers, and some couples; in Pittsburgh the methodology included one fathers' focus group and additional data taken from a father involved in a long-term, intensive-case study. In Kansas City, the study included interviews of seven fathers (three interviewed as part of a couple), two grandfathers, and nine mothers (three as part of a couple). All seven of the fathers were living with their children and their mothers, and three of the mothers were living with their child's father. Approximately half of these respondents were in the research program and the remaining in the comparison group; they had been involved in the study for 6 months to 1 year at the time of the interviews. Children of these parents ranged from three months to 18 months of age at the time of their interviews. In Brattleboro, the fathers' focus group consisted of four fathers being served by the EHS program, and the mothers' group likewise consisted of four mothers who were in the program; all participants were part of intact couples, though the eight participants did not represent couples with each other. Children of these participants ranged in age from 2 months to 42 months at the time of the focus groups. In Denver, four focus groups were conducted: two with fathers (five in an English-language group and three in a Spanish-language group), and two with 
mothers (six in an English-language group and five in a Spanish-language group). All participants were part of intact families at the time of selection, though one man and his girlfriend separated before the groups actually met. All participants were being served by the program, which had been open only 5 months when the focus groups were conducted. Children of these focus group participants ranged from 2 to 17 months at the time of the study. In Pittsburgh, two fathers attended a focus group, and eight mothers participated in a separate focus group. The Pittsburgh case study data for this report was taken from an ongoing case study being conducted with a father who is a primary caregiver for his child. All participants had been served by the program for less than a year at the time of the study; their children ranged in age from 2 to 18 months.

The first stage of data analysis was completed independently at each of the four sites. That is, researchers at each site analyzed the transcripts of their own interviews or focus groups, to develop a set of emergent themes (Strauss \& Corbin, 1990). The resulting site reports were circulated to all four sites. For stage two of the analysis, the investigators at each of the four sites content analyzed each others' reports to identify common themes, which were confirmed and discussed via telephone conference. Based on this consensus-building process, a matrix of cross-site responses was developed (Miles \& Huberman, 1994), to facilitate comparison of both unique and common points that emerged.

\section{RESULTS}

Table 1 is the analytical matrix displaying the cross-site responses to the question about fathers' role perceptions. While there were some differences across the four sites, there were also some similarities. In general, parents tended to talk about roles in terms of their child's needs, or the functions parents play in meeting those needs. Those mentioned in two or more of the four sites included: providing financial support, "being there" for the child, providing routine care giving, engaging in play, outings and activities, serving as teacher, role model, and disciplinarian, providing love and affection, and serving as a protector. The following sections provide a more in-depth analysis of the respondents' understanding of these roles.

\section{Financial Support}

Respondents in all four sites mentioned financial support to some degree, although it was not the most emphasized role. For example, in Denver, fathers explicitly rejected the idea that their primary responsibilities were as providers. While these men all planned to meet their financial obligations, they were concerned that they do more than simply provide money. Nevertheless, financial obligations were a responsibility that all these men felt, and even in the context of relationship difficulties, they argued that they still would support their children financially. Likewise in Kansas City, Brattleboro, and Pittsburgh, fathers spoke of pragmatic responsibilities like money management and bread winning, but quickly moved on to talk of their need to be "more than a provider." In response to questions about welfare reform, there was talk of "deadbeat dads," and approval of provisions to enforce child support. Because these men were all involved fathers, it is not difficult to understand that support was a "given" or basic foundation, to be mentioned before moving on to other themes.

Beyond basic survival, some of the Kansas City respondents talked about support in the context of providing "extras"; in fact, some saw it as a matter of pride when they were able to get things that were beyond basic food and shelter, to "spoil" their children, or "give them more" than they themselves had. One father said, "I feel like I'm being a good father when we're getting the things we like. We can wear jewelry now, and pay our bills on time . . And I got enough to buy him stuff, to make him happy." Several of the mothers-primarily 
TABLE 1. Cross-Site Comparison of Perceived Fathers' Roles

\begin{tabular}{|c|c|c|c|}
\hline Kansas City. Kansas & Brattleboro, Vermont & Demer, Colorado & $\begin{array}{l}\text { Pittsburgh, } \\
\text { Pennsyhania }\end{array}$ \\
\hline $\begin{array}{l}\text { - financial support, "ex- } \\
\text { tras" } \\
\text { —-"being there," physical } \\
\text { and emotional availa- } \\
\text { bility; } \\
\text { - care giving, as supple- } \\
\text { meat to mother or } \\
\text { equal participant (ex- } \\
\text { pressed by mothers) } \\
\text { - recrention, outings } \\
\text {-guidnuce and disci- } \\
\text { pline } \\
\text { - providing protection }\end{array}$ & $\begin{array}{l}\text { - money management } \\
\text { and bread winning } \\
\text { - family participation } \\
\text {-engagement with child } \\
\text { - responsibility for child } \\
\text { care tasks (expressed } \\
\text { by mothers) } \\
\text { - spending time and } \\
\text { playing } \\
\text { - teaching, modeling. } \\
\text { motivating child } \\
\text {-executor of fomily dis- } \\
\text { cipline }\end{array}$ & $\begin{array}{l}\text { - household decision } \\
\text { maker } \\
\text { - financial provision } \\
\text { - "being there" } \\
\text { - equal care giving (ex- } \\
\text { pressed by mothers) } \\
\text { - recrention } \\
\text { - discipline and guid- } \\
\text { ance } \\
\text { - love for child } \\
\text { - shared emotions } \\
\text { - ediucacion (e.g., moral } \\
\text { development, respect) }\end{array}$ & $\begin{array}{l}\text {-economic provider } \\
\text { - "being there," provid- } \\
\text { ing care and comfort } \\
\text { - being dependable } \\
\text { - equal care giving (ex- } \\
\text { pressed by mothers) } \\
\text { - connection with bio- } \\
\text { logical father } \\
\text { - protection from injus- } \\
\text { tice }\end{array}$ \\
\hline
\end{tabular}

younger, unmarried respondents in their teens or early twenties - did not seem to expect basic child support, but instead saw fathers as responsible for "buying things," which meant "extras" such as toys, clothes, disposable diapers, and food.

\section{"BeingThere"}

Mothers and fathers in all four sites used the phrase "being there" in reference to fathers' roles. For some respondents, their experiences with their own fathers or fathers they knew, created a minimum expectation that fathers should be present or available to the child, that is, "not running off." For example, one Kansas City mother, asked what she was proudest of about her family, responded: "I'm proud her father's here . . . 'cause I mean, other girls, they babies' daddies just walk off and leave 'em and I'm proud of that 'cause I thought I was going to end up the same way."

Other responses, however, suggest that the phrase "being there" conveyed more than a minimum expectation and included physical presence and emotional engagement. The Pittsburgh respondents, for example, drew a distinction between "fathers" and "dads": A "father" is someone who "makes a baby," but a "dad" is someone who is "there" for the child. Mothers in the Pittsburgh group engaged in an emotional discussion over this issue, describing their own lack of connection to, even lack of knowledge of, their biological fathers, which they did not want their children to experience.

\section{Care Giving}

In the area of providing day-to-day care for children (e.g., diapering, feeding, bathing, etc.), there was a striking difference in all four sites between the mothers and the fathers who participated in the study. In Kansas City, this parenting role was described by some fathers as "watching the baby," that is, providing babysitting on an occasional basis when the mother had something else to do. Some of the Kansas City mothers also described their baby's fathers as taking the child for visits or weekends to his mother's home, or otherwise arranging for the paternal extended family to assume some of the care. 
In general, however, fathers did not mention care giving as a responsibility, while mothers held lengthy discussions about the responsibilities of fathers to take on child care duties, as well as their frequent failure to do so. In Brattleboro, for example, mothers expressed their greatest appreciation for or desire for father involvement in pragmatic terms and defined fathers' engaged involvement more by accomplishment of mundane child-care tasks. In Denver, mothers in the English-language focus group similarly emphasized that dads were easily engaged in fun activities with their children, for example, going out to eat, going to the amusement park, etc., but they complained that they were of little use when it came to child-care responsibilities. Interestingly, this complaint was not emphasized in the Spanish-language group, where it seemed that mothers had less of an expectation that fathers would participate in child care.

\section{Outings, Activities, and Play}

Fathers in all four sites talked about the importance of spending time and playing with their children, taking them on outings, or simply holding them. In speaking of what their own fathers did with them or how they expected to be involved with their children, fathers referred to activities like sports, hunting, fishing, or other similar outings, and fathers without transportation, asked what else they would like to do with their children if they could, responded that they would like to be able to take their children places - to the country, to the park, to see things. One mother, angry because she perceived that her baby's father had abandoned his responsibilities, addressed the question of what she will do differently because her child's father was not in the picture, saying it was "those father-son things, you know, teaching him how to play football. Taking him fishing, all that kind of stuff. Now I'm going to have to do that stuff."

Fathers described most of their play interactions with young children as physical, rough and tumble play, such as wrestling, tickling, and bouncing the baby. In this regard, there appear to be gender differences in just how fathers play with daughters versus their sons. With boys, there was more talk of rough play, and of introducing their sons to the wider world and to things such as sports, fishing, and hunting. With girls, the play was more gentle and there was a perception that girl children were more fragile. One Kansas City father (who had brother- sister twin infants) described his playtime with the children: "With this one we wrestle, and he just laughs and giggles ... with her I do that little neck nuzzle and tickle thing. . . . I got to have one come up feminine and one come up manly ... But the love is totally the same." Thus, play, outings, and recreation appear to have a purpose in these fathers' eyes, related to socializing their children.

\section{Teaching, Modeling, and Discipline}

Respondents in all four sites referred to the father's role in providing guidance and discipline to children. This was expressed as trying to "guide them to do right," that is, stepping in and providing structure and discipline for children. In Brattleboro, for example, one mother expressed her desire for her husband "to teach my daughter about those men that she should stay away from." In Pittsburgh, fathers talked about being a positive role model and providing moral guidance, "being a good teacher about life." In contrast to care giving (which apparently was seen - by fathers at least - as a primary role for the mother), guidance and discipline was seen by at least some respondents as a primary task for the father. For example, one Kansas City father, asked about the unique contribution of fathers to their 
children ("What difference do you think there is in your child's life as opposed to those where the father isn't there?"), responded that he thought single mothers were perfectly capable of "laying down rules," and so therefore there should not be any difference. Thus, while he tried to express his egalitarianism, the fact that this general question led him to consider the issue of discipline, suggests that many men may perceive being a disciplinarian as primarily a paternal role.

In Denver, this guidance role was expressed with the Spanish word educacio'n, which includes but has a much broader meaning than the provision of formal education. Among the fathers in the Spanish-language group, this term encompassed learning right from wrong, proper behavior with others, the importance of work and providing for one's family. One of the fathers said, "the primary school is the home," and he described how he took care to avoid violence in the home for fear of the kind of example it would set for his son.

\section{Providing Love}

In Denver and Pittsburgh, respondents talked about the importance of fatherly love for one's child. In Colorado, one father described, in particularly poignant detail, how he would share positive and negative affect with his child, participating at an emotional level in his son's joys and sorrows. In Pittsburgh, fathers focused very much on the affective side of the affective/ instrumental dichotomy of parenting roles. Through both words and gestures (e.g., holding arms as if cradling a baby), these fathers presented a striking picture of fatherhood as an intimate physical and emotional presence in the life of the young child. On the other hand, mothers in the Pittsburgh group presented a slightly different picture. While they emphasized that fathers should do all the things that mothers do, their list of what they expected from fathers had a slight emphasis on the instrumental, that is, physical care giving and financial support. While these mothers did insist on a lack of role differentiation, they also asserted that the emotional bond with the baby is different for fathers and mothers. Although they had difficulty articulating this difference, it appeared that, from their perspective, the bond is closer and more intimate with the mother.

\section{Protection}

Kansas City and Pittsburgh fathers described themselves as having a protective role with respect to their children and families. Pittsburgh dads, for example, focused on the father's importance in providing protection not only from physical danger but also from social and economic injustice, helping kids through "thick and thin," and "knocking some of the rough edges off of life for them." In Kansas City, fathers' comments about the need to protect their families were made in the context of questions about what worried them as parents, or in the context of questions about what they would change about their neighborhoods. One father described his anxiety about Sudden Infant Death syndrome, and spoke of regularly getting up in the night to check all his children. Another father described speaking to neighbors about their disruptive or "bullying" children. Several fathers also described restricting their child or their partner from access to perceived bad influences or dangerous situations. This included restricting a child to the yard or the house because of violence in the neighborhood, or forbidding a wife to visit a relative who was a perceived bad influence. Another type of protection involved taking action, such as moving to a safer neighborhood, or taking other positive actions to assure a safe environment for the child. 


\section{DISCUSSION}

It should be noted that the majority of fathers who participated in this pilot study were living with their children and their children's mothers at the time they were interviewed. Thus, our findings represent a profile of paternal role perceptions of low-income parents living in families where the father is currently strongly involved. We recognize that this type of co-residential family structure represents only about half of the families being served in Early Head Start programs. Restricting this study sample to this type of family was deliberate: its purpose was to establish a benchmark or foundation describing the range of roles parents perceive important for fathers to play when they are in an environmental context that is considered most supportive for optimal father involvement (Doherty et al., 1998). Doherty et al. (1998) propose a conceptual model that takes into account a variety of environmental, co-parental, child, mother, and father factors and characteristics that may have an impact on fathering. Thus, the primary value of this pilot study should be seen as providing a backdrop for future studies exploring role perceptions of fathers in other contextual situations.

The contexts of fathering differ greatly in the four sites, with wide variances in ethnic group membership, culture, and rural-urban environments. These differences account for some of the variations in respondents' comments, for example, with respect to concerns for safety expressed by fathers in the urban sites, and also with respect to greater emphasis on more traditional roles expressed by Hispanic families in Denver. Given these differences, as well as the different methodologies used, it is remarkable that there were so many consistent responses across the four sites. Thus, it may be, drawing upon the model proposed by Doherty et al. (1998) that the more salient environmental context shaping these respondents' perceptions may be the within-family consistency, that most of these families were living as two-parent households. This observation fits with the conclusions of McBride \& Rane (1997), who emphasize the importance of the mother's perception of the father role in shaping both paternal perception of the role and the father's actual involvement with the child. Regardless of the reasons behind these observed cross-site consistencies, they present us with an opportunity to draw some conclusions about the results of this pilot study.

\section{Relation to Theoretical Frameworks}

How does the aggregated wisdom of ordinary people fit with the frameworks proposed by family theoreticians? The dimensions of involvement proposed by Lamb et al. (1987) included engagement, accessibility, and responsibility, characterized by some commentators as a "content- free" structure for considering fatherhood roles (e.g., Doherty et al., 1998). As described, however, parents who participated in this study were not content-free in their observations, but rather focused on fathers' roles related to their children's needs.

Table 2 is a matrix analyzing the relationship of the needs-based roles to the dimensions of father involvement in the Lamb et al. (1987) framework. Only one of the roles identified in this study seems to fall discretely into one or another end of the involvement continuum: providing financial support. Financial support appears exclusively to be an indirect type of involvement representing "responsibility," as defined by Lamb et al. (1987). For the other roles, the examples given by these respondents seem to fall into two or more of the dimensions of involvement. For example, the concept of "being there" seems at first glance to fall into the dimension of accessibility (i.e., physical presence), yet respondents also described "being there" as encompassing a much more intimate level of emotional engagement with the child. As another example, respondents perceived the role of disciplinarian or teacher as being accomplished through direct engagement with the child (teaching, disciplining) and by presenting a 
TABLE 2. Comparison of Percerved Father Roles Identified by Pilot Study Respondents with the Lamb et al. (1987) Framework for Father Dnohement

\begin{tabular}{|c|c|c|c|}
\hline & Engagement & Accessibility & Responsibility \\
\hline Financial support & - & - & Providing basic support \\
\hline "Being there" & $\begin{array}{l}\text { Bmotional engagement; } \\
\text { Listening }\end{array}$ & Physical presence & - \\
\hline Care giving & Providing basic care & Staying with sick child & $\begin{array}{l}\text { Arranging child care with } \\
\text { pateral relatives }\end{array}$ \\
\hline $\begin{array}{l}\text { Outing5, activities, } \\
\text { Piny }\end{array}$ & $\begin{array}{l}\text { Physical play; } \\
\text { Father-chld outings }\end{array}$ & $\begin{array}{l}\text { Family outings } \\
\text { and activities }\end{array}$ & - \\
\hline $\begin{array}{l}\text { Guidance, discipline, } \\
\text { Teaching }\end{array}$ & $\begin{array}{l}\text { Discipline; } \\
\text { Teaching }\end{array}$ & Role modeling & - \\
\hline Providing love & $\begin{array}{l}\text { Holding, rocking, touch- } \\
\text { ing the baby }\end{array}$ & Sharing joys and sorrows & - \\
\hline Protection & $\begin{array}{l}\text { Setting safe limits and } \\
\text { rules }\end{array}$ & $\begin{array}{l}\text { Providing watchful pres- } \\
\text { ence }\end{array}$ & $\begin{array}{l}\text { Assuning a safe environ- } \\
\text { ment }\end{array}$ \\
\hline
\end{tabular}

visible model of "doing right" through the father's own actions. Still other father roles were to be achieved through all three dimensions of involvement. For example, care giving included engaging in basic-care routines, being present or available (e.g., when the child is ill), and taking responsibility for arranging child care with paternal relatives. Similarly, the protection role was fulfilled through setting limits with the child, being present and available to mediate conflicts, and taking responsibility for assuring the family is living in a safe environment.

One conclusion to draw from this conceptual exercise is that mothers and fathers may perceive that meeting the full range of children's needs requires father involvement across all three dimensions of the involvement continuum (Lamb et al., 1987). Further research may identify father activities that allow us to "fill in" the matrix in cells where the current study provided no immediate examples.

A further use of this matrix may be to serve as a tool for exploration of the impacts of different contextual factors on fathering. How are these roles accomplished (or not) when an involved father is not living with the mother and child, or when the father is more uninvolved? Is there a perceived "hierarchy" of involvement? If, indeed, the mother's perception of paternal roles is critical to fathers' involvement (McBride \& Rane, 1997), are there particular roles, such as providing support, that represent an "entry ticket" in their own minds or in the minds of mothers, to allow fathers to address other roles? Another question is, how do these roles interact? Also, do families with different cultural backgrounds or at different life stages (i.e., families of young vs. families of older children) emphasize different roles to a greater or lesser degree? If so, does a greater emphasis on one role facilitate or preclude accomplishment of other roles? For example, do particular approaches to "traditional" father roles such as administering discipline, affect a father's ability to provide love and emotional engagement? Alternatively, the question might be: is a balance of attention to these roles needed for fathers to promote optimal well-being in their children, or do different culturally approved emphases on a few or some of these roles produce equally acceptable results?

\section{“Traditional” versus Co-Parenting Roles}

The low-income participants in this pilot study seem to be engaged as much as the rest of American society in debates about the relative roles of mothers and fathers in the lives of their 
children (Doherty et al., 1998). Comments by these mothers and fathers suggest that determining role perceptions along a continuum from more traditional role separation to co-parenting, (e.g., as suggested by Pleck \& Pleck, 1977) is a complex process. For one thing, mothers and fathers may be using different perceptual lenses. For example, the mothers in this study tended to be vociferous in their assertion that they wanted fathers to be "fifty-fifty" partners in the more mundane tasks of care giving for infants, while fathers seemed to be more or less oblivious of care giving as a role to be mentioned at all.

In addition, these respondents might be seen as viewing each of the roles discussed with different lenses in terms of the traditional versus co-parenting dichotomy. Both mothers and fathers appear to believe it appropriate to share some roles, but not equally. In some cases parents may view mothers as having "executive" or primary responsibility for some parenting roles, with fathers in a subordinate or secondary position. Equally, fathers may be viewed as "in charge" of some roles with mothers providing secondary support. For example, fathers in this study described examples of their actions and expressed opinions consistent with studies of other low-income or African-American fathers (e.g., Allen \& Doherty, 1996) suggesting they viewed themselves as serving as primary protectors, economic providers, and family disciplinarians, with mothers serving that role either in the father's absence (e.g., viewing single mothers as capable of "laying down rules" if needed), or under their partner's supervision.

The concept of unequal role-sharing may explain the difference in perceptions about care giving, if mothers (much to their chagrin) are still viewed as being the "chief executive" with respect to this role. However, there are forces at work that may influence a change in perceptions of this role toward more equal co-parenting. Already, $23 \%$ of families with a working mother have a father who serves as the primary parent while the mother works (U.S. Bureau of the Census, 1996). As welfare reform brings more mothers into the labor force, even more low income families may solve their child care needs through a "split shift" strategy, in which one parent works nights or evenings while the other works in the daytime. Thus, more and more fathers, particularly in blue-collar and low-income families where "off-time" jobs are more plentiful, may increasingly be thrust into a greater care giving role.

The idea that mothers and fathers may perceive themselves as having primary or secondary responsibility for some parenting roles, should be considered a tentative hypothesis to emerge from this pilot study. The implications of such a hypothesis are that father roles cannot be considered without taking into account the reciprocal perception of appropriate mother roles, and perceptions held about the interactions between the two. It adds yet another layer of complexity to the model suggested by Lamb et al. (1987), and lends support to the framework for understanding father involvement proposed by Doherty et al. (1998), which takes into account a variety of contextual factors, including the mother's influence. The concept of "primary" and "secondary" role sharing between mothers and fathers suggests a variety of questions for future study. At a minimum, it may be useful to determine whether perceptions of mothers' roles can also be classified in the Lamb et al. (1987) framework for engagement, accessibility, and responsibility, and if so, whether they form a similar, reciprocal, or overlapping pattern with the father roles identified in Table 2. Other questions include: what is the impact of "splitshift" parenting on family and marital quality of life? What are the impacts of mothers taking greater responsibility for discipline, on fathers' relationships with their children? What are the dynamics of co-parenting when parents do not live together?

\section{Next Steps}

As is the case of any exploratory, grounded-theory investigation, this study raises more questions than it resolves. Based on these preliminary results, a study of the role perceptions of a larger number of fathers involved in the Early Head Start Research Consor- 
tium programs, will determine the degree to which this small pilot sample reflects the perceptions and beliefs of the broader population of low-income fathers of young families. In the meantime, however, it should be remembered that this study, of fathers who are either living with or heavily involved with their child, should be considered as a frame of reference for study of those families in which the father is peripherally involved or not involved at all. The first question for that group, as suggested by McBride and Rane (1997) is whether mothers and fathers consider father involvement to be as important in the lives of their children as do the families in this study. If they do hold views of fathers as necessary components for the family (e.g., Allen \& Doherty, 1996), then the question becomes, why are they not involved?

A second question is whether fathers who hold the perception that they should be involved across the continuum of involvement, and through the range of needs of their child, are able to use that perception as an insulation against the forces of poverty and other institutional barriers that impede their ability to be an effective presence in their child's life. If so, this may lead to development of policies and support services that nurture those perceptions and build on them to enhance the well-being of fathers and their children.

\section{REFERENCES}

Allen, W.D., \& Doherty, W.J. (1996). The responsibilities of fatherhood as perceived by African American teenage fathers. Families in Society: The Journal of Contemporary Human Services, 77, 142-155.

Bryan, D.L. \& Ajo, A.A. (1992). The role perception of African American fathers. Social Work and Research Abstracts, 28(3), 17-21.

Cazenave, N.A. (1979). Middle income black fathers: An analysis of the provider role. The Family Coordinator, 28(4), 583-593.

Glaser, B.G., \& Strauss, A.L. (1967). The discovery of grounded theory: Strategies for qualitative research.

Chicago: Aldine. Doherty, W.J., Kouneski, E.F., \& Erickson, M.F. (1998). Responsible fathering: An overview and conceptual framework. Journal of Marriage and the Family, 60(2), 227-292.

Goetz, J.P., \& Lecompte, M.D. (1984). Ethnography and qualitative design in educational research. New York: Academic Press.

Harold-Goldsmith, R., Radin, N., \& Eccles, J.S. (1988). Objective and subjective reality: The effects of job loss and financial stress on fathering behaviors. Family Perspective, 22, 309-325.

Jain, A., \& Belsky, J. (1997). Fathering and acculturation: Immigrant Indian families with young children. Journal of Marriage and the Family, 59, 873-883.

Janesick, V.J. (1994). The dance of qualitative research design: Metaphor, methodolotry, and meaning. In N.K. Denzin \& Y.S. Lincoln (Eds.), Handbook of qualitative research (pp. 209-219). Thousand Oaks, CA: Sage.

Jones, L. (1991). Unemployed fathers and their children: Implications for policy and practice. Child and Adolescent Social Work Journal, 8, 101-116.

Lamb, M.E. (1987). Introduction: The emergent American father. In M.E. Lamb (Ed.), The father's fole: Cross-cultural perspectives (pp. 3-25). Hillsdale, NJ: Erlbaum.

Lamb, M.E., Frodi, A.M., Hwang, C.P., \& Frodi, M. (1982). Varying degrees of paternal involvement infant care: Attitudinal and behavioral correlates. In M.E. Lamb (Ed.), Nontraditional families: Parenting and child development (pp. 117-137). Hillsdale: NJ: Erlbaum.

Lamb, M.E., Pleck, J.H., Charnov, E.L., \& Levine, J.A. (1985). Paternal behavior in humans. American Zoologist, 25, 883-894. 
Lamb, M.E., Pleck, J.H., Charnov, E.L., \& Levine, J.A. (1987). A biosocial perspective on paternal behavior and involvement. In J. Lancaster, J., Altmann, A., Rossi, \& L. Sherrod (Eds.), Parenting across the lifespan: Biosocial dimensions (pp. 111-142). Hawthorn, NY: Aldine de Gruyter.

Larossa, R., \& Reitzes, D. (1993). Continuity and change in middle-class fatherhood: 1925-1939. Journal of Marriage and the Family, 55, 455-468.

Levy-Shiff, R., \& Israelashvili, R. (1988). Antecedents of fathering: Some further exploration. Developmental Psychology, 24, 434-440.

McBride, B.A., \& Rane, T.R. (1997). Role investments and paternal involvement. Early Childhood Research Quarterly, 12, 173-197.

McBride, B.A., \& Rane, T.R. (1998). Parenting alliance as a predictor of father involvement: An exploratory study. Family Relations, 47, 229-236.

McLanahan, S.S., Astone, N.M., \& Marks, N.F. (1991). The role of mother-only families in reproducing poverty. In A.C. Husten (Ed.), Children in poverty (pp. 51-78). New York: Cambridge University Press.

Marsiglio, W., \& Day, R., With Braver, S., Evans, V.J., Lamb, M., \& Peters, E. (1997). Social fatherhood and paternal involvement: Conceptual, data, and policymaking issues. Presented at the NICHD sponsored Conference on Fathering and Male Fertility: Improving Data and Research. Bethesda, MD, March.

Miles, M.B., \& Huberman, A.M. (1994). Qualitative data analysis. Thousand Oaks, CA: Sage.

Mincy, R.B. (1997). Delivering dads: Paternalism and fragile families. In L. Mead (Ed.), The new paternalism: Supervisory approaches to poverty reduction. Washington, DC: The Brookings Institute.

Pleck, E.H., \& Pleck, J.H. (1997). Fatherhood ideals in the United States: Historical dimensions. In M.E. Lamb (Ed.), The role of the father in child development (3rd ed.). New York: Wiley.

Pleck, J.H. (1997). Paternal involvement: Levels, sources, and consequences. In M.E. Lamb (Ed.), The role of the father in child development (3rd ed.). New York: Wiley.

Price-Bonham, S., \& Skeen, P. (1979). A comparison of black and white fathers with implications for parent education. The Family Coordinator, 28(1), 53-59.

Peplau, L.A. (1983). Roles and gender. In H.H. Kelley, E. Berscheid, A Christensen, J.H. Harvery, T.L. Huston, G. Levinger, E. McClinctock, L.A. Peplau, \& D.R. Peterson (Eds)., Close relationships (pp. 220264). New York: Freeman.

Rubin, H.J., \& Rubin, I.S. (1995). Qualitative interviewing: The art of hearing data. Thousand Oaks, CA: Sage.

Silverstein, L.B. (1996). Fathering is a feminist issue. Psychology of Women Quarterly, 20, 3-37.

Strauss, A., \& Corbin, J. (1990). Basics of qualitative research: Grounded theory procedures and techniques. Newbury Park, CA: Sage.

U.S. Bureau of the Census (1996). Who's minding our preschoolers? (Current Population Reports, Series P7053). Washington, DC: U.S. Government Printing Office. 